\title{
Glial Cells and Products of Activated Inflammatory Cells: Implications for Pathogenesis and Treatment of Multiple Sclerosis
}

\author{
R. P. Lisak \\ Departments of Neurology and Immunology and Microbiology, Wayne State University School of \\ Medicine, Detroit MI, and University of Pennsylvania School of Medicine, Phialdelphia, PA, USA
}

Multiple sclerosis (MS) is an inflammatory demyelinating disease of the central nervous system of unknown etiology, but a disease in which immunopathologic events are likely important [1]. It is a chronic disease, frequently with an clinically relapsing course [2], but the pathologic processes may actually be continuous, although accentuated at times [3]. It also has a restricted age distribution, with the peak onset between 20 and 40 years of age. In addition to the inflammation, which is predominantly made up of monocyte-macrophage-microglia and lymphocytes and/ or their progeny, and demyelination, the other characteristic pathologic feature is gliosis [4]. This gliosis relates to the astrocytes, although there is some controversy as to whether these cells become more prominent, increase in number, or both.

There has been considerable interest in the possibility that MS is an autoimmune immunopathologic disease with a component of myelin/oligodendrocyte, the target for an antibody and/or cellular response. To date, the evidence is indirect $[5,6]$ and the antigen has certainly not been unambiguously identified [7]. More recently, there has been increasing interest in other interactions between the immune and nervous systems. This has been made possible by several scientific advances, including the ability to identify, purify, and study the function of subsets of cells of both the immune and nervous system as well as to purify and characterize secretory products of cells of both systems. In addition, genetic engineering has allowed the production of single products of inflammatory cells, and the use of monoclonal antibodies allows the unequivocal identification of epitopes of important surface and cytoplasmic components of cells of the nervous system on the immune system. Much of this recent activity has centered on interactions between products of activated inflammatory cells (cytokines=lymphokines + monokines) and glial cells [oligodendrocytes, astrocytes, macrophages, microglia (brain phagocytic cells)] and brain vascular endothelial cells $[8,9]$. These cytokines are clearly present in the nervous system and CSF of patients with MS [10]. An extension of this line of investigation is the study of glial cells serving functions traditionally associated with cells of the immune system such as presentation of antigen [11], production of monokines [12, 13], phagocytosis [14], and production of enzymes such as proteases which could contribute to myelin breakdown and even act as stimulators of B-cell proliferation and differentiation [15]. Although much has been learned, there are many unanswered questions of considerable neurobiologic, immunologic, and pathologic importance. 
Which products of activated inflammatory cells are mitogenic for which types and subtypes of glial cells?

The work of several groups $[8,9,16,17]$ makes it clear that unfractionated supernatants from activated inflammatory cells induce proliferation of astrocytes and CNS origin fibroblasts in vitro. As noted earlier, there is clearly gliosis associated with long-standing lesions of patients with MS, with the suggestion that astrocytes may undergo swelling, show an increase in intermediate filaments, and perhaps proliferate. In acute experimental allergic encephalomyelitis (EAE) as well as in the chronic and relapsing forms of the disease, astrocytes are also similarly affected. We do not know whether all astrocytes are affected equally [18]. Type II astrocytes, which in rats seem to arise from the same precursor glioblasts as oligodendrocytes $[19,20]$, are more numerous in white matter and some may be intimitely related to the paranodal region of the myelinated CNS axon [21]. Thus, it is conceivable that changes in this subclass of astrocyte, including proliferation, changes in phenotypic markers and functions, swelling, and failure to perform normal astrocytic functions, could lead to changes in CNS nerve conduction and result in symptoms. If the changes do not lead to demyelination or gliosis, it is possible that there might be rapid improvement in symptomatology. Could this be one of the mechanisms responsible for the rapid and often clinically complete recovery seen after exacerbations, especially during early phases of the disease?

Fontana's group [8, 16, 22, 23] performed preliminary studies on activated supernatants and identified a factor which seemed to induce astrocyte proliferation. There has been no further published work characterizing the factor further, which seemed to be a product of $\mathrm{T}$ cells, nor do we know is it has any effect on oligodendrocytes, microglia, or Schwann cells. Is it the only mitogen for astrocytes produced by $\mathrm{T}$ cells? It most likely is not the only mitogen produced by inflammatory cells since it has been shown that interleukin-1 (IL-1) (produced by macrophages and perhaps microglia and astrocytes themselves) induces astrocyte proliferation $[17,24]$. It is of some interest that Schwann cells, at least cells from neonatal rat sciatic nerves, do not proliferate in direct response to IL-1 in vitro [25].

It has been reported that $\mathrm{T}$-cell products stimulate oligodendrocytges to proliferate in vitro [26]. A $30000 \mathrm{~mol}$. wt. protein is said to induce proliferation of oligodendrocytes and no other CNS, PNS, or non-NS cells [27]. Based on the mol. wt. of 30000 , as well as its reported very restricted selectivity as a mitogen, it seems unlikely to be IL-1, interleukin-2 (IL-2), or Fontana's glial proliferative factor. We have been unable to demonstrate that unfractioned activated supernatants, IL-2, or $\gamma$-interferon $(\gamma$-IF) induce proliferation of oligodendrocytes [28]. Others have reported that IL-2 is mitogenic for oligodendrocytes [29], but at a very high concentration. Although cloned IL-2 has been used by both our group as well as those who detect a proliferative effect, the results differ. The need for very high concentrations to induce proliferation suggests either an effect of some carrier material or that oligodendrocytes have either very low density of IL-2 receptors or low-avidity receptros. Neonatal Schwann cells do not proliferate in vitro in response to IL-2, although they proliferate in response to the unfractionated supernatants of activated inflammatory cells [30]. It is not clear why these differences in results occur, but species and in vivo age of animals as well as in vitro age of cultures may explain some but not all of the conflicts. The question of the effect of age may be 
important in consideration of which products of activated inflammatory mononuclear cells are capable of induction of major histocompatibility complex (MHC) antigens and which glial cells are susceptible to MHC antigen induction. Since the onset of MS shows age restriction and the pattern of clinical disease may differ in part related to the patient's age, the possible effect of age and the response to cytokines may be important.

Supernatants obtained from activated mononuclear cells have been reported to induce MHC type I antigens (HLA-A, B, C in man) on oligodendrocytes, astrocytes, and microglia-macrophages [28, 31-35]. The demonstration that type I antigens can be induced on a cell type which ordinarily does not bear such antigens is not trivial since it has been demonstrated that T-cell-mediated antigen-specific cytotoxic reactions against cellular antigens, including viral antigens in such cells, can only occur if the cells bear MHC type I antigens [36]. If glial cells serve as targets for such antigen-specific cytotoxic reactions in MS and other diseases, it would be required that type I MHC antigens be induced by a lymphokine, such as $\gamma$-IF, or by a viral infection [37]. There is much written about the search for type II (Ia) MHC antigens on glial cells in lesions of patients with MS but little about type I antigens on such glial cells. Parenthetically, such studies are likely forthcoming and we will need to remember that in a disease like MS that has periods of varying activity and a chronic course we may expect variable reports from different groups. The may be studying different lesions in different patients, or indeed different lesions in the same patient [38].

There is also interest in the question of which cells in the CNS naturally bear or can be induced to bear MHC type II (Ia) antigens (DR, DQ in man). It has been reported that activated antigen-specific T-cell lines, which would be capable of production and secretion of lymphokines including $\gamma$-IF, and $\gamma$-IF itself can induce Ia on astrocytes $[8,9,11)$ which are ordinarily la negative [39]. These astrocytes can then present myelin basic protein (MBP) to the T-cells. It is a "requirement" for antigen-presenting cells to have type II on their surface. Recently, it has been reported that oligodendrocytes can have an accessory function on in vitro T-cell mitogenesis [40], but this is a different phenomenon from specific antigen presentation and antigen-specific proliferation. There is little evidence, if any, that oligodendrocytes become la positive in vitro or in vivo [39, 41, 42]. It has been reported, however, that astrocytes in MS and EAE lesions are type II MHC positive $[10,43]$. Based on the earlier described in vitro evidence, it has been postulated that antigen presentation by astrocytes may contribute to propagation of inflammatory lesions in the CNS. Astrocyte lysis by MBP-specific T-cells has also been described [44].

The situation regarding astrocytes is not as straight forward as it had seemed. In EAE lesions in rats, macrophages become strongly positive before a relatively small percentage of astrocytes become Ia positive [45, 46]. We and others have not found induction of Ia on most astrocytes in vitro [28, 35]. Microglia-macrophages are the predominant Ia-positive cells in normal cultures [35,39] and after induction [28, 35]. MHC antigens are glycoproteins and may be found on cells adjacent to the cell that is actually producing la; i. e., it may be very difficult to localize la [35]. Disparity between immunofluorescence and immunoperoxidase techniques, and light and electron microscopic localization of Ia has been reported in other organs [47]. Cells 
which are passively Ia positive likely do not function as antigen-presenting cells. Therefore, it will be important to determine, both in vitro and in vivo, if astrocytes or even oligodendrocytes actually can be induced to become la positive and which cytokines induce the antigens. It will likely require molecular biologic techniques, such as in situ hybridization combined with immunohistology, ultimately to settle the question.

What is the role of vascular endothelial cells in the initiation of and selfpropagation of immunopathologic reactions with the CNS?

There is growing evidence that the endothelial cells of cerebral blood vessels may play an active rather than passive role in immunopathologic reactions within the CNS [9]. There have been reports of DR (Ia) on CNS endothelial cells in the CNS of animals with EAE [45, 46]. However, this has not been a universal finding and, more recently, it has been suggested that it is actually perivascular dendritic (microglia) that are the positive cells in the CNS vessels [49]. It has been reported that similar Ia localization is seen in MS lesions [50, 51], but, again, the exact nature of the positive cells in uncertain. It would not be surprising if a macrophagemicroglial cell among the endothelial cells were induced to become Ia positive and interact with circulating T-cells, even presenting antigen [52]. It should be noted that how T-cells circulating at a high flow rate interact with endothelial or dendritic cells is still not clear. Changes in the endothelium could also allow passage of nonspecific inflammatory cells or serum proteins which could induce demyelination [53-55]. On the other hand, some of the changes reported in CNS vasculature in MS are seen in classic passive transfer delayed hypersensitivity reactions. Further comparative studies of passive and active EAE are clearly of importance here as are in vitro studies of endothelial cell-cytokine interactions and lymphocyte-endothelial cell interactions. It must also be remembered that the frequency of CNS antigen-specific T-cells is probably very different in animals with actively induced EAE, passively transferred EAE, and EAE passively transferred with T-cell lines or clones. Moreover, T-cell lines and clones, especially after reactivation or restimulation, may differ quantitatively and qualitatively from "normal" $\mathrm{T}$-cells in many in vitro and in vivo characteristics.

For the most part, I have emphasized the potential pathogenic importance of the interactions of cytokines and glial cells, and I belive we are just beginning to understand this important area. Clearly, there are tremendous therapeutic implications. It has been traditional to consider how drugs and modifiers of biologic reactions would interact with the classic cells of immunopathologic reactions ( $\mathrm{T}$ cells, B-cells, monocyte-macrophages, and, more recently, K and NK-cells). The reports of some [56-59] but not all groups [60-62] of a defect of NK-cell function associated with (or perhaps caused by) a decreased $\gamma$-IF production in patients with MS lead to the suggestion that $\gamma$-IF might be of benefit in MS. Recently, a therapeutic study demonstrated that $\gamma$-IF was associated with an increase in exacerbations [63]. This might relate to activation of circulating cells of the immune system, but it is also possible that immunologic cells within the nervous system or glial cells were affected directly by $\gamma$-IF crossing a damaged blood-brain barrier [64]. Since glial cells have been postulated to produce IL-1 $[8,12]$ and proteases (which could interact with B-cells) [15], activation of glial cells by systemically administered lymphokines could also have a deleterious effect in an indirect fashion. Rather than 
looking for biologic modifiers for treatment of MS, we may need antibodies directed against the modifier or its receptor.

There are other possible cytokine-glial cell interactions that have therapeutic implications. $\alpha$ - and $\beta$-IF inhibit cellular proliferation, as does $\gamma$-IF, under certain circumstances [65]. If the astrocytic response in MS is deleterious, then an inhibitory effect by one of the interferons or other biologic modifier might have a long-term beneficial effect in MS. However, if oligodendrocyte or oligodendrocyte precursor proliferation were inhibited by an exogenously administered agent, that might prove to be harmful. It has been reported that IL-2 induces synthesis of myelin-specific constituents, such as MBP, by oligodendrocytes [29]. Thus, inhibition of IL-2 production or blocking of IL-2 receptors, if present, on glial cells would be potentially harmful, even if inhibition of the effect of IL-2 on T or B-cells might be potentially helpful. Until we know more about the in vivo and in vitro effects of the many cytokines, as well as the effects of inhibition of the cytokines and their receptors, we are guessing in planning therapeutic studies.

Although there is no substitute for eventually performing well-controlled studies in patients, we need to learn much more about in vitro and in vivo effects of various potential biologic agents on glial cells before embarking on more and more treatment studies in patients.

\section{References}

1. Lisak RP (1980) Multiple sclerosis: evidence for immunopathogenesis. Neurology 30 (2): 99-105

2. Poser CM, Alter M, Sibley WA, Scheinberg LC (1984) Demyelinating diseases, 129. Multiple sclerosis. In: Rowland LP (ed) Merritt's Textbook of Neurology. Lea and Febinger, Philadelphia, pp 593-611

3. Naharona ABC, Richman DP, Arnason BGW (1980) Detection of in vivo stimulated cerebrospinal fluid lymphocytes by flow cytometry inpatients with multiple sclerosis. N Engl J Med 303: 713-717

4. Prineas JW (1985) The neuropathology of multiple sclerosis. In: Koetsier JC (ed) Clincial handbook of neurology, vol 47, demyelinating diseases. Elsevier, Amsterdam, pp 213-257

5. Reder AT, Arnason BGW (1985) Immunology of multiple sclerosis. In: Koetsier JC (ed) Clinical Handbook of neurology, vol 47, demyelinating diseases. Elsevier, Amsterdam, pp $337-$ 396

6. Lisak RP (1986) Immunologic abnormalities. In: McDonald WL, Silberberg DH (eds) Multiple sclerosis, Butterwort medical reviews, neurology, vol 6. Butterworths, London pp 74-98

7. Lisak RP, Zweiman B, Burns JB, Rostami A, Silberberg DH (1984) Immune responses to myelin antigens in multiple sclerosis. Ann NY Acad Sci 436: 221-230

8. Fontana A, Grob PJ (1984) Lymphokines and the brain (DeWeck, AL guest ed). Springer Semin. Immunopathol. 6:375-386

9. Fontana A, Fierz W (1985) The endothelium-astrocyte immune control system of the brain. (Steck AJ, Lisak RP guest eds). Springer Semin Immunopathol 8: 57-70

10. Hofman FM, von Hanwehr RI, Dinarello CA, Nigel SB, Hinton D, Merrill JE (1986) Immunoregulatory molecules and IL-2 receptors identified in multiple sclerosis brain. J Immunol 136: 3239-3248

11. Fontana A, Fierz W, Wekerle H (1984) Astrocytes present myelin basic protein to encephalitogenic T-cell lines. Nature 307: 276

12. Fontana A, Kristensen F, Dubs R, Gemsa D, Weber E (1982) production of prostaglandin E and interleukin-1 like factors by cultured astrocytes and C-6 glioma cells. J Immunol 129: 2413-2419 
13. DuBois JH, Bolton C, Cuzner ML (1986) The production of prostaglandin and the regulation in neonatal primary mixed glial cultures. J Neuroimmunol 11:277-285

14. Naske W, Lantzen H, Lange K, Keller K (1982) Phagocytic activity of glial cells in culture. Exper Cell Res 142: 437-445

15. Bever CT, Whitaker JN (1985) Proteinases in inflammatory demyelinating disease. (Steck AJ, Lisak RP guest eds). Springer Semin Immunopathol 8: 235-250

16. Fontana A, Greider A, Arrenbrecht ST, Grob P (1980) In vitro stimulation of glial cells by a lymphocyte-produced factor. J Neurol Sci 46: 55-62

17. Grulian D, Lachman LB (1985) Interleukin-1 stimulation of astroglial proliferation after brain injury. Science 228: 497-499

18. Miller RH, Abney ER, David S, French-Constant C, Lindsay R, Patel R, Stone J, Raff MC (1986) Is reactive gliosis a property of a distinct subpopulation of astrocytes? J Neurosci 6: 22-29

19. Raff MC, Nuller RH, Noble M (1983) A glial progenitor cell that develops into an astrocyte or oligodendrocyte depending on culture medium. Nature 303:390-396

20. Raff MC, Abney ER, Cohen J, Lindsay R, Noble M (1983) Two types of astrocytes in cultures of developing rat white matter: differences in morphology, surface gangliosides, and growth characteristics. J Neurosci 3: 1289-1300

21. Waxmann SG (1986) The astrocyte as a component of the node of Ranvier. Trends Neurosci: 250-253

22. Fontana A, Dubs R, Merchant R, Balsiger S, Grob PJ (1981) Glial cell stimulation factor (GSF): a new lymphokine. Part I. Cellular sources and partial purification of murine GSF, role of cytoskeleton and protein synthesis in its production. J Neuroimmunol 2:55-71

23. Fontana A, Otz U, De Weck AL, Grob PJ (1981) Glial cell stimulating factor (GSF): a new lymphokine, part II. Cellular sources and partial purification of human GSF. J Neuroimmunol 2:73-81

24. Lisak RP, Kuchmy D, Pleasure DE unpublished observations

25. Lisak RP, Kuchmy D, Guerrero F, Pleasure DE (1986) $\gamma$-interferon and interleukin-1 are not mitogenetic for neonatal Schwann cells in vitro. Neurology 36 (Suppl): 313

26. Merrill JE, Kutsunai S, Mohlstrom C, Hofman F, Groopman J, Golde DW (1984) Proliferation of astroglia and oligodendroglia in response to human T-cell derived factors. Science 224: 1428

27. Benveniste EN, Merrill JE, Kaufman SE, Golde DW, Gasson JC (1985) Purification and characterization of a human T lymphocyte-derived glial growth-promoting factor. Proc Natl Acad Sci USA 82:3930-3934

28. Suzumura A, Silberberg DH, Lisak RP (1986) The expression of MHC antigens on oligodendrocytes. Induction of polymorphic $\mathrm{H}-2$ expression by lymphokines. J Neuroimmunol 11: 179190

29. Benveniste EN, Merrill JE (1986) Stimulation of oligodendroglial proliferation and maturation by interleukin-2. Nature 321:610--613

30. Lisak RP, Sobue G, Kuchmy D, Burns JB, Pleasure DE (1985) Products of activated lymphocytes stimulate Schwann cell mitosis in vitro. Neurosci Lett 57:105-111

31. Hirsch MR, Wietzerkin J, Pierres M, Goridis C (1983) Expression of Ia antigens by cultured astrocytes treated with gamma-interferon. Neurosci Lett 41: 199-204

32. Wong GHW, Bartlett PF, Clark-Lewis I, Battye F, Schraeder J (1984) Inducible expression of H-2 and Ia antigen on brain cells Nature 310:688-691

33. Wong GHW, Bartlett PF, Clark-Lewis I, McKimm-Breshken JL, Schroeder W (1985) Interferon- $\gamma$ induces the expression of $\mathrm{H}-2$ and Ia antigens on brain cells. J Neuroimmunol 7: 225-279

34. Suzumura A, Silberberg DH (1985) Expression of H-2 antigen on oligodendrocytes is induced by soluble factors from Concanavalin-A activated T-cells. Brain Res 336:171-175

35. DuBois JH, Hammond-Tooke GD, Cuzner ML (1986) Expression of major histocompatibility complex antigens in neonatal rat primary mixed glial cultures. J Neuroimmunol 9:363-377

36. Zinkernagel RM, Doherty PC (1979) MHC restricted cytotoxic T-cells: studies on the biological role on polymorphic major transplantation antigens, determining $\mathrm{T}$-cell restriction specificity function and responsiveness. Adv Immunol 27: 52-177

37. Suzumura A, Lavi E, Weiss SR, Silberberg DH (1986) Neurotropic coronavirus infection induces H-2 antigen expression on oligodendrocytes and astrocytes. Science 232: 991-993 
38. Zweiman B, Lisak RP (1986) Lymphocyte phenotypes in the MS lesion. What do they mean? Ann Neurol 19:588-589

39. Lisak RP, Hirayama M, Kuchmy D, Rosenzweig A, Kim SU, Pleasure DE, Silberberg DH (1983) Cultured human and rat oligodendrocytes and rat Schwann cells do not have immune response gene associated antigen (Ia) on their surface. Brain Res 289: 285-292

40. Cashman NR, Nohorona A (1986) Accessory cell competence of ovine oligodendrocytes in mitogenic activation of human peripheral T-cells. J Immunol 136: 4460-4463

41. Ting JPY, Shigekawa BL, Linthicum DS, Weiner LP, Frelinger JA (1981) Expression and synthesis of murine immune response-associated (Ia) antigen by brain cells. Proc Natl Acad Sci USA 78: 3170-3174

42. Ting JPY, Nixon DF, Weiner LP, Frelinger JA (1983) Brain Ia antigens have a bone marrow origin. Immunogenetics 17: 295-301

43. Traugott U, Scheinberg LC, Raine CS (1985) On the presence of Ia-positive endothelial cells and astrocytes in multiple sclerosis lesions and its relevance to antigen presentation. $J$ Neuroimmunol 8: 1-14

44. Sun D, Wekerle H (1986) Ia restricted encephalitogenic T lymphocytes mediating EAE lyse autoantigen-presenting astrocytes. Nature 320:70-72

45. Hickey WF, Osborn JP, Kirbi WM (1985) Expression of Ia molecules by astrocytes during acute experimental allergic enephalomyelitis in the Lewis rat. Cell Immunol 91:528-535

46. Vass K, Lassmann H, Wekerle H, Wisniewski HM (1986) The distribution of Ia antigen in the lesions of rat acute experimental allergic encephalomyelitis. Acta Neuropathol 70:149-160

47. Kornstein MJ, Brooks JJ, Anderson AO, Levinson AL, Lisak RP, Zweiman B (1984) The immunohistology of the thymus in myasthenia gravis. Am J Pathol 147: 184-194

48. Sobel RA, Calvin RB (1985) The immunopathology of experimental allergic encephalomyelitis (EAE). Differential in situ expression of Strain 13 Ia on endothelial and inflammatory cells of (Strain 2+Strain 13) F1 guinea pigs with EAE. J Immunol 134:2333-2337

49. Matsumato Y, Hara N, Tanaka R, Fujiwara M (1986) Immunohistochemical analysis of the rat central nervous system during experimental allergic encephalomyelitis, with special reference to la positive cells with dendritic morphology. J Immunol 136:3668-3676

50. Traugott U (1985) Characterization and distribution of lymphocyte subpopulations in multiple sclerosis plaques versus autoimmune demyelination lesions. (Steck AJ, Lisak RP guest eds) Springer Semin Immunopathol 8: 71-96

51. Traugott U, Raine CS (1985) Multiple sclerosis. Evidence for antigen presentation in situ by endothelial cells and astrocytes. J Neurol Sci 69:365-370

52. McCarron RM, Spatz M, Kempski O, Hogan RN, Muehl L, McFarlin DE (1986) Interaction between myelin basic protein-sensitized $\mathrm{T}$ lymphocytes and murine cerebrovascular vascular endothelial cells. J Immunol 137:3428-3435

53. Sergott RC, Brown MJ, Polenta RM-D, Lisak RP, Silberberg DH (1985) Optic nerve demyelination induced by human serum: patients with multiple sclerosis or optic neuritis and normal subjects. neurology 35: 1438-1442

54. Hirayama M, Lisak RP, Silberberg DH (1986) Serum-mediated oligodendrocyte cytotoxicity in multiple sclerosis patients and controls. Neurology 36:276-278

55. Suzumura A, Lisak RP, Silberberg DH (1986) Serum cytotoxicity to oligodendrocytes in multiple sclerosis and controls: assessment by ${ }^{51} \mathrm{Cr}$ release assay. J Neuroimmunol 11:137-147

56. Neighbour PA, Bloom BR (1979) Absence of virus-induced lymphocyte suppression and interferon production in multiple sclerosis. Proc Natl Acad Sci USA 76: 476-480

57. Neighbour PA (1984) Studies of interferon production and natural killing by lymphocytes from multiple sclerosis patients. Ann NY Acad Sci 436: 181-191

58. Salonen R, Ilonen J, Reunanen M, Nikoloskelainen J, Salmi A (1982) PPD-, PWM-, and PHAinduced interferon in stable multiple sclerosis: association with HLA-Dw ${ }^{2}$ antigen and clinical variables. Ann Neurol 11:279-284

59. Vervhet G, Claeys H, van Hover H, Carton H, Vermylen C, Meulepas E, Billiau A (1983) Interferon production and natural killer (NK) activity in leukocyte cultures from multiple sclerosis patients. J Neurol Sci 60: 134-150

60. Santoli D, Hall W, Kastroukoff L, Lisak RP, Perussia B, Trinchieri G, Koprowski H (1978) Cytotoxic activity and interferon production by lymphocytes from patients with multiple sclerosis. J Immunol 126: 1274-1278 
61. Kaudewitz P, Zander H, Abb J, Ziegler-Heitbrock HW, Riethmuller G (1983) Genetic influence on natural cytotoxicity and interferon production in multiple sclerosis in monozygotic discordant twins. Hum Immunol 7:51-58

62. Tovell DR, McRobbie IA, Warren KG, Tyrrell DL (1983) Interferon production by lymphocytes from multiple sclerosis and non-MS patients. Neurosci Behav Physiol 33: 640-643

63. Pannitch HS, Haley AS, Hirsch RL, Johnson KP (1986) A trial of gamma interferon in multiple sclerosis: clinical results. Neurology 36 (Suppl 1): 285

64. Lisak RP (1986) Interferon and multiple sclerosis. Ann Neurol 20: 273

65. Taylor-Papadimitrou J (ed) (1985) Interferons. Their Impact in Biology and Medicine, Oxford University Press, Oxford 